\title{
PERFORMANCE ANALYSIS OF THE RESTAURANT AND HOTEL INDUSTRY: EVIDENCE FROM BORSA ISTANBUL
}

DOI: 10.17261/Pressacademia.2019.1110

JEFA- V.6-ISS.3-2019(1)-p.115-123

\section{Nida Turegun}

Ozyegin University, School of Applied Sciences, Cekmekoy, Istanbul, Turkey. nida.turegun@ozyegin.edu.tr , ORCID ID: 0000-0002-1912-5095

Date Received: June 6, 2019

Date Accepted: August 18, 2019

To cite this document

Turegun, N. (2019). Performance analysis of the restaurant and hotel industry: evidence from Borsa Istanbul. Journal of Economics, Finance and Accounting (JEFA), V.6(3), p.115-123.

Permemant link to this document: http://doi.org/10.17261/Pressacademia.2019.1110

Copyright: Published by PressAcademia and limited licenced re-use rights only.

\section{ABSTRACT}

Purpose - The aim of this study is to apply factor analysis to financial ratios of companies in Restaurant and Hotel industry by showing up the best ratio among each factor group and to detect the performance differences between restaurants and hotels.

Methodology - The sample data cover between the years 2009 and 2018 of 13 observed companies at Borsa Istanbul. This study works on the financial ratios of the companies as performance variables. Factor analysis and the discriminant analysis is applied.

Findings - The results reveal that cash, return on equity, accounts receivable and inventory turnover are the key ratios. Moreover, hotels are differentiated by their high liquidity, receivables, and turnover ratios, where restaurants are differentiated by their profitability and solvency ratios.

Conclusion -, the restaurants are more capable to satisfy their long-term debts. They have equal or even better performance when compared with their profit-oriented counterparts.

Keywords: Ratio analysis, discriminant analysis, performance analysis, Borsa Istanbul, restaurant and hotel industry JEL Codes: M40, M41, M49

\section{INTRODUCTION}

The tourism industry can be classified as travel, hospitality, transportation, food and beverage, recreation and leisure. Hospitality is the most important sector and takes the first place in tourism industry. On the other hand, restaurants or Food and Beverage (F\&B) is an important element that complements hospitality. Restaurant sector is the second most important sector in tourism industry (MEGEP, 2011).

The Restaurant and Hotel industry was always an inseparable part of the Turkish economy. It is one of the most crucial industries in Turkey, except for the crisis years and "non-planned period (1923-1963)". The industry showed unbelievable growth after 1980. Turkey's amazing nature and convenient prices attract tourists, especially who are coming from Central Europe and Post- Soviet states. However, in recent years' terror attacks and political conflicts caused significant damages to the industry. Nevertheless, Turkey is still an important player in the world tourism. Therefore, the Turkish Restaurant and Hotel industry has been studied in this paper as an example of a developing country. This study can be used as a guide for the investors in other developing countries who are planning to invest in the industry (Turizmin, 2011).

Tourism activity mainly covers travel and temporary accommodation. In the whole process, there is a more compulsory need for people to resolve, which is food and beverage. Although the two sectors are intrinsically different, they are very closely connected to each other. Thus, hospitality and restaurants are considered as one industry in stock exchange markets. There are performance analysis studies regarding to this industry, however there is a gap in comparing the performances of hotels and restaurants separately in literature.

Therefore, the aim of this study is to fill the existing research gap in Turkey, to analyze and compare the performance of restaurants and hotels in the industry. The sample data cover between the years 2009 and 2018 of 13 observed companies. 
In total, there are 130 firm-years. This study work on the financial ratios of the companies as performance variables. Factor analysis is conducted to summarize the performance variables and then discriminant analysis is applied to detect performance differences between groups. SPSS 22.0 has been used for the statistical part of the study.

The present study provides evidence that hotels are differentiated by their high liquidity (cash, quick, current), receivables, and turnover ratios. Restaurants are differentiated by their profitability and solvency ratios (ROE, Debt to Equity, ROS). The restaurants can have equal or even better performance when compared with their profit-oriented counterparts. These results are important for numerous stakeholders like internal and external decision makers, accountants and auditors.

The rest of the paper is organised along these lines. Part 2 provides the literature review on performance and factor analysis for hospitality and F\&B industry. Part 3 explains the ratios used in the study. Part 4 displays the structure and methodoloy. Part 5 specifies data collection. Part 6 presents analysis and results. Finally, Part 7 presents the study's conclusions.

\section{LITERATURE REVIEW}

Performance analysis has been a subject area which has been receiving sufficient interest of numerous researchers in recent years (Feng, \& Wang, 2000; De et al., 2011; Delen et al., 2013). The authors are drawn to the study of performance analysis to understand how the recent financial ratios has influenced it (Kim, \& Ayoun, 2005; Kim \& Kim, 2005; Chen, 2010).

There are various studies conducted in this framework for hospitality and F\&B industry, for instance, the recent ones conducted by Mardahleni, 2018; Lai, 2018; Vatalis, 2018; Pudjisuryadi et al., 2018; Tan, 2018; Naumik-Gladkaya, \& Devon, 2018; Tamallo, 2018. However, all of these studies are allied to different countries or regions. Therefore, this study deepens this research by using restaurant and hotel firms in Turkey, which have different features with respect to the level of external impact in business operations and economic changes.

The aim of this study is to fill the existing research gap in Turkey and to apply factor analysis to financial ratios by showing up the best ratio among each factor group and to detect the performance differences between Hotels and restaurants. Pinches et al. were the first to apply factor analysis to financial ratios in 1973, in a study of U.S. industrial firms (Pinches et al., 1973). After 1973, many studies applied this practice to minimize the number of ratios selected and redundancy among them. Most of the studies are in the manufacturing and retailing industries. The focal point of this study is directed to the Restaurant and Hotel industry to group factors whose financial features vary from manufacturing and retailing.

There are several works on applying factor analysis to financial ratios in Turkey. In the study of "Performance of direct foreign investments in Turkey" the author used a factor analysis to financial ratios of foreign-owned firms with domestically owned firms. Then the author applied discriminant analysis and logistic regression (Karataş, 2002).

In the study of "Prediction of corporate financial distress in an emerging market: The case of Turkey", the authors used factor analysis to financial ratios and conducted discriminant analysis to predict the failures (Uğurlu, \& Aksoy, 2006).

In the study of "Industry financial ratios-application of factor analysis in Turkish construction industry", the authors applied factor analysis to financial ratios for Turkish construction companies (Ocal et al., 2007).

In the study of "Applying Factor Analysis on the Financial Ratios of Turkey's Top 500 Industrial Enterprises", the author applied factor analysis to financial ratios for 500 industrial companies in Turkey (Erdoğan, 2014).

There are also studies that apply ratio analysis to restaurants and hospitality industry without computing factor analysis. The international studies can be counted as Damitio et al., 1995; Singh \& Schmidgall, 2001; Singh \& Schmidgall, 2002; Böcskei, 2014; Arif et al., 2016; Bala et al., 2016; Abdul Aziz \& Rahman, 2017, Vaško, 2018 and Ziskos, 2019. The studies that are conducted in Turkey can be counted as Karadeniz \& İskenderoğlu, 2014; Karadeniz et al., 2014; Ecer \& Günay 2014; Özçelik \& Kandemir, 2015; Şen et al., 2015; Bilici \& Aydın, 2018, and Aslan \& Yılmaz, 2018.

Thus, extends the literature by focusing on an emerging economy and to the best of our knowledge, this is the first study that detect performance differences restaurants and hotels with the case of listed firms in the Turkish setting. Moreover, the Turkish data represents an example for similar practices of other emerging economies. The present study attempts to bridge the gap in the literature by providing the performance differences between restaurants and hotels in the context of the economy of Turkey that is a study area which was previously unexplored.

\section{RATIO ANALYSIS}

Ratio analysis plays a huge role in terms of analyzing financial statements, comparison of performance, making plans, detecting positive and negative sides, opportunities and threats. Being able to analyze investor ratios might signify the distinction between devoting the resources into a decent promising and potentially successful company or an awful one.

Therefore, having access and interpreting these numbers are important for an investor. It creates advantages in terms of investments' comparison, and also mediate the right strategies from the aspect of trade and minimizes failing to meet 
expectations on stocks. Comparing the figure of the balance sheet, income statement and cash flow create a scale to measure the likelihood of the financial safety of corporations.

In this study, this paper focuses on applying factor analysis to the financial ratios of the restaurants and hotels, which are quoted on Borsa Istanbul. This study uses current, quick, cash, return on assets, return on equity, return on sales, earnings per share, debt to equity, debt to assets, interest coverage, accounts receivable turnover, inventory turnover, and total assets turnover ratios.

Current, quick, and cash ratios are selected for this study since they are especially valuable for corporate officials. Return on assets, return on equity, return on sales, and earnings per share are selected since they are especially valuable for finance executives. Debt to equity, debt to assets, and interest coverage ratios are selected since they are especially valuable for brokers. Accounts receivable turnover, inventory turnover, and total assets turnover ratios are selected since they are especially valuable for managers (Kim, \& Ayoun, 2005). Table 1 shows the summary table for ratios.

Table 1: Summary Table for Ratios

\begin{tabular}{|c|c|c|}
\hline Ratio & Formula & Indicates \\
\hline Current & Current Assets / Current Liabilities & $\begin{array}{l}\text { whether a company's current assets are adequate to pay } \\
\text { back its current liabilities and estimates its short-term } \\
\text { financial health }\end{array}$ \\
\hline Quick & $\begin{array}{l}\text { Current Assets - Inventories } \\
\text { / Current Liabilities }\end{array}$ & $\begin{array}{l}\text { the ability of a company to pay its current liabilities with } \\
\text { its quick assets }\end{array}$ \\
\hline Cash & Cash / Current Liabilities & $\begin{array}{l}\text { company's ability to pay back its current liabilities with its } \\
\text { cash and cash equivalents }\end{array}$ \\
\hline Return on Assets & Net Income / Total Assets & $\begin{array}{l}\text { how effectively companies turn their assets to generate } \\
\text { profit }\end{array}$ \\
\hline Return on Equity & Net Income / Owner's Equity & $\begin{array}{l}\text { how much gain a corporation made on the money that } \\
\text { investors paid }\end{array}$ \\
\hline Return on Sales & Net Income / Total Sales Revenue & $\begin{array}{l}\text { company's operating performance, and its ability to } \\
\text { generate profits on sales }\end{array}$ \\
\hline Earnings per Share & $\begin{array}{l}\text { Net Income } \\
\text { / Common Shares Outstanding }\end{array}$ & $\begin{array}{l}\text { how many dollars of net income earned by each share of } \\
\text { common stock }\end{array}$ \\
\hline Debt to Equity & Total Liabilities / Owner's Equity & $\begin{array}{l}\text { proportion of equity and debt a company is using to } \\
\text { finance its assets }\end{array}$ \\
\hline Debt to Assets & Total Debt / Total Assets & $\begin{array}{l}\text { the financial leverage, shows the rate of total assets } \\
\text { which financed with debt }\end{array}$ \\
\hline Interest Coverage & $\begin{array}{l}\text { Earnings Before Interest \& Taxes } \\
\text { / Interest Expense }\end{array}$ & the ability of a company to meet its interest payments \\
\hline Acc. Rec. Turnover & $\begin{array}{l}\text { Net Credit Sales } \\
\text { / Average Accounts Receivable }\end{array}$ & how many times a company collects its receivables \\
\hline Inventory Turnover & Cost of Goods Sold / Inventory & the efficiency of managing and selling of inventories \\
\hline T. Assets Turnover & Net Sales / Total Assets & $\begin{array}{l}\text { how efficiently a company can use its assets to generate } \\
\text { sales }\end{array}$ \\
\hline
\end{tabular}




\section{STRUCTURE AND METHODOLOGY}

The following indicates the brief of all the objectives this research will provide to:

- $\quad$ reveal the ratios in terms of liquidity, profitability, solvency and activity performances of the restaurants and hotels quoted on Borsa Istanbul.

- $\quad$ analyze and compare the performance of the restaurants and the hotels in the industry.

- $\quad$ summarize the performance variables.

- detect performance differences between groups.

The structure of this study is based on factor and discriminant analysis. Factor analysis is a multiple variable statistic that aimed to discover a few conceptually significant variables with bringing together many variables which are connected with each other. By applying factor analysis to financial ratios of the restaurants and hotels quoted on Borsa Istanbul, this study examined covariance structure of some group variables and explained relations between each other in point of unobservable hidden variables which are much less than others. Discriminant analysis is a statistical technique that helps to comprehend the differences between the two groups. By applying discriminant analysis to restaurants and hotels, this study aims to detect performance differences between those groups.

Ratios which belong to certain groups measure the same parameter and give the same results with using same denominators. In order to understand the best ratio to measure one parameter, we need to use factor analysis. So, it is possible to find the best ratios to measure parameters by reducing a large number of the same ratios to a minimum. Also, it helps to arrange background for further detailed statistical studies. In other words, the structure of this study will be created by using analytic technic that aimed to reach a few explanatory factors which explain maximum variance and have calculation logic which to base relation between expected variables.

The main purpose of this study to reveal the ratios in terms of liquidity, profitability, solvency and activity performances of the restaurants and hotels quoted on Borsa Istanbul. Moreover, to analyze and compare the performance of the restaurants and the hotels in the industry. This study work on the financial ratios of the companies as performance variables. Factor analysis is conducted to summarize the performance variables and then discriminant analysis is applied to detect performance differences between groups.

\section{DATA COLLECTION}

In this research, the publicly traded restaurant and hotel companies quoted on Borsa Istanbul are examined for 10 years of reporting period between 2009 and 2018. The reason for using this period is that the last five years of investigation is the most essential average year number for investors to make decisions. There are only 13 firms in total quoted in Borsa Istanbul for the Hospitality and F\&B industry. The required data of the hotels and restaurants quoted on Borsa İstanbul between the years 2009 and 2018 have obtained from "Public Disclosure Platform".

SPSSC 22.0 program is used for the analysis of the data. The sample data is covered between 2009 and 2018 with 13 observations. In total, there are 130 firm-years. The unit of measurement is the Turkish Lira (TL).

\section{ANALYSIS AND RESULTS}

The raw data collected from 13 companies are transferred to the SPSS program. The outputs of descriptive statistics and explanatory factor analysis are generated. In total, there are 130 firm-years with a sample size of 1690 . The analysis has done for all of the 13 ratios, however the total assets turnover, return on assets, interest coverage and earnings per share were excluded respectively due to invalid results. The analysis has rerun after each change.

Table 2 shows the descriptive statistics for the ratios from the final analysis. According to Table 1, the mean for the current ratio is 2,9. It means a company's current asset of 2,9 dollars for every 1 dollar of current liability. The common acceptable value is 2 for the current ratio and having a higher ratio is good for the Restaurant and Hotel industry. This industry relies heavily on short-term liabilities in the form of salaries and wages and equipment leasing. However, restaurants have lower current ratio than hotels. This high ratio indicates that companies can easily pay their short-term liabilities. 
Table 2: Descriptive Statistics

\begin{tabular}{|l|l|l|l|}
\hline Ratio & Mean & Std. Deviation & Analysis N \\
\hline Current & 2,90960 & 3,510500 & 130 \\
Quick & 2,52083 & 3,346807 & 130 \\
Cash & 1,44758 & 3,278934 & 130 \\
ROE &, 298293 &, 6536663 & 130 \\
ROS &, 859145 & 1,6704056 & 130 \\
Debt to Equity & 1,10285 & 3,263789 & 130 \\
AccRecTurn & 30,652354 & 110,5459597 & 130 \\
Inv Turn & $-20,269688$ & 69,5202020 & 130 \\
\hline
\end{tabular}

The mean for the quick ratio is 2,5 . The commonly acceptable ratio is 1 , but this may differ from industry to industry. A value that is greater than 2 is considered as good. A high quick ratio or a value with an increasing trend indicates the revenue growth. Moreover, it means a company is collecting its receivables, turning over its inventories and converting them into cash. Meaning the hotels are selling their rooms and the restaurant are selling their dishes. However, restaurants have lower quick ratio values than hotels.

The mean for the cash ratio is 1,4 . The commonly acceptable proportion is 0.50 to 1 . The high level of cash ratio indicates low short-term leverage and indebtedness. The mean for return on equity (ROE) is 0,29 . or $29 \%$. $15 \%$ and higher values are considered as good. This high ROE value indicates a high value for the stock prices.

The mean for return on sales (ROS) is 0,85 or $85 \%$. The ROS shows the profit from a company's sales. This is a high return which indicates that the Restaurant and Hotel industry is selling their products well and their profits are high.

The mean for the debt to equity ratio is 1.10 . A commonly acceptable ratio is 1.5 and less. This value indicates that the Restaurant and Hotel industry have no problem to meet its long-term liabilities and have lower risk since the debt holders have fewer rights on the company's assets.

The mean for the accounts receivable turnover is 30 . This means the accounts receivable turned over 30 times. The Restaurant and Hotel industry rely heavily on short-term debt and the short-term debt should be paid back less than 60 days. The value of this ratio indicates that companies operate on a cash basis and their accounts receivable collection is efficient.

The mean for the inventory turnover ratio is -20 . This means strong sales and no excess of inventory. This negative number indicates that hotels are selling their rooms before the accommodation.

The convenience of ratio variables for factor analysis was tested via Barlett Test of Sphericity and the Kaiser-Meyer-Olkin Measure of Sampling Adequacy Test (KMO). The end result value of KMO is 0.783 , and Bartlett is 0.000 that is smaller than 0.05 , which means the observed variables are suitable for factor analysis. 


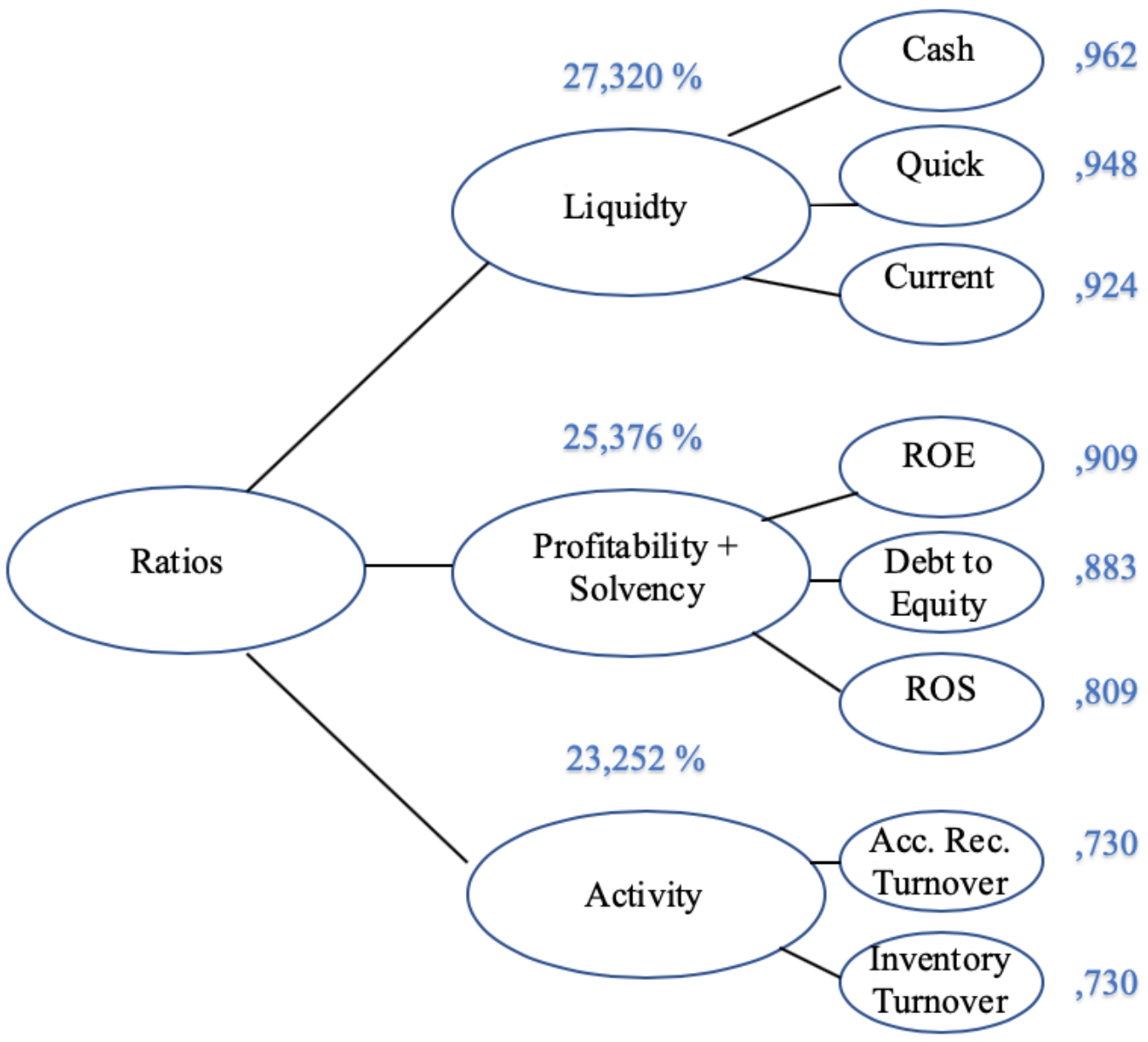

Figure 1 displays a whole picture of the analysis results. Each of the ratios has a correlation with a value higher than 0,5 at the anti-image correlation matrix. According to the figure three components are extracted. The names are given to the components according to the ratio types. Three components are liquidity, profitability + solvency, and activity. total variances explained for the liquidity is $27,320 \%$, profitability + solvency is $25,376 \%$ and activity is $23,252 \%$.

The liquidity component has three ratios, which are cash, quick and current ratios. The factor loadings for cash ratio is 0,962 , quick is 0,948 and current is 0,924 . The profitability + solvency component has three ratios, which are ROE, debt to equity and ROS. The factor loadings for ROE is 0,909 , debt to equity is 0,883 and ROS is 0,809 . The activity component has two ratios, which are accounts receivable turnover and inventory turnover. The factor loadings for accounts receivable turnover is 0,730 and inventory turnover is 0,730 . The results indicate four important ratios according to their factor loadings for investors, which are cash, ROE, accounts receivable turnover and inventory turnover. Instead of examining all liquidity, profitability, solvency and activity ratios, investors can base their decision on these four ratios.

The case processing summary, which is necessary for reliability analysis, shows that all the variables are valid. Reliability analysis is necessary to find the numerical reliability of every dimension after factor analysis. When analyzing reliability, the Alpha model should be used. Cronbach's Alpha is a value of concordance depends on a correlation between variables. This value is accepted if it is higher than 0.70 . Cronbach's Alpha value is 0,939 for the liquidity component, 0,779 for the profitability + solvency component and 0,711 for the activity component, which means our model is reliable. Each of the ratio values is lower than Cronbach's Alpha value if the item is deleted.

After extracting the components, the discriminant analysis is performed. According to the analysis, the Box's $M$ test is significant with a value of 0,055, 0,053 and 0,052 for liquidity, profitability + solvency, and activity dimensions respectively. According to the pooled within-group matrices, each of the variable's correlation for each of the dimensions are under 0,70 . 
The canonical correlation is $0,884,0,847,0,820$ and $\%$ of variance are $78 \%, 75 \%, 73 \%$ for the liquidity dimension, profitability + solvency and activity dimensions respectively. According to the Wilk's lambda $22 \%, 25 \%$ and $27 \%$ cannot be explained by the differences between the groups for the liquidity dimension, profitability + solvency, and activity dimensions respectively.

\section{Figure 2: Industry's Differentiated Ratios}
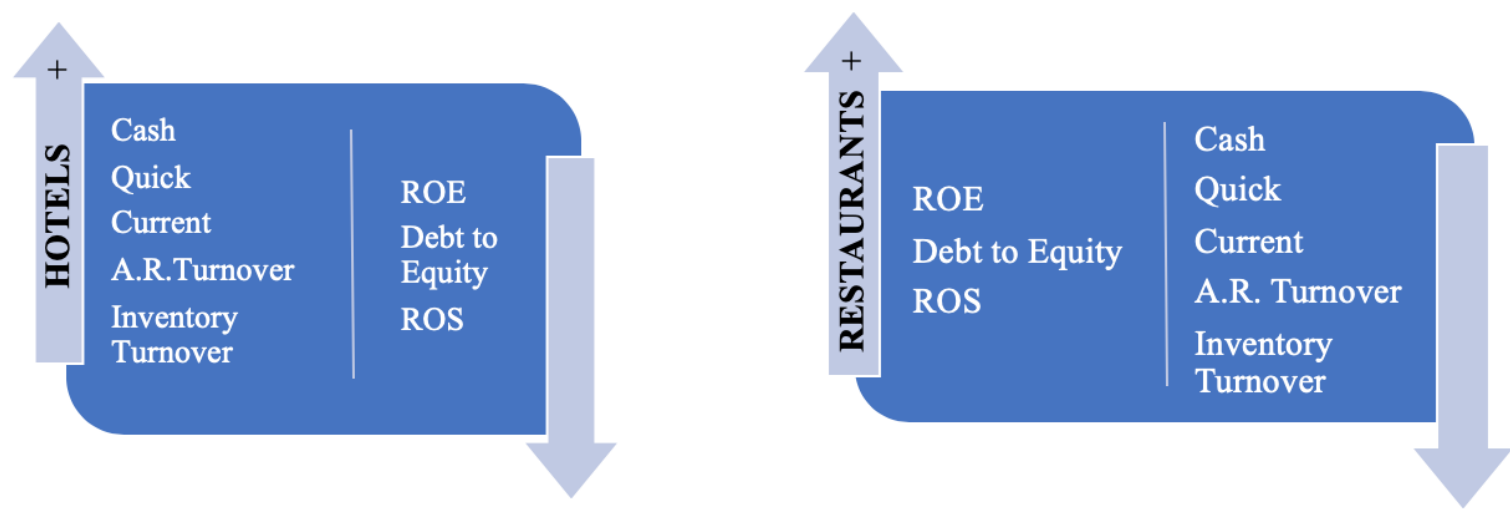

Figure 2 shows the industry's differentiated ratios. The differentiated ratios are given on the left sides of the figures and they are sorted from the highest to lowest order in terms of differentiation. The findings suggest that hotels are differentiated by their high liquidity ratios (cash, quick, current), high receivables and turnover ratios. Restaurants are differentiated by their profitability and solvency ratios (ROE, Debt to Equity, ROS).

\section{CONCLUSION}

This study acts as a bridge for expanding the understanding of performance analysis and provides real-world implications for firms with regard to satisfying stockholders and attracting potential investors. This study can be used as a guide for the investors in other developing countries who are planning to invest in the industry.

The Restaurant and Hotel industry in Turkey relies heavily on short-term liabilities in the form of salaries and wages and equipment leasing, but the companies in the industry can easily pay their short-term liabilities. Likewise, they operate on a cash basis, collect their receivables efficiently, turn over their inventories and convert them into cash quickly. Moreover, they have low short-term leverage. They have strong sales. Their profits and the value for the stock prices are high. They have no problem to meet its long-term liabilities and have lower risk since the debt holders have fewer rights on the company's assets.

It is very important to outline a set of financial ratios of the Restaurant and Hotel industry to be used in the comparative analysis and to make deductions depend on performances of the companies. The findings identified four important ratios for the investors in the hospitality industry. These ratios are cash, ROE, accounts receivable turnover and inventory turnover. Instead of examining all liquidity, profitability, solvency and activity ratios, investors can base their decisions on these four ratios. By evaluating these four resources, investors can comment on the return and risk of their investments with greater accuracy.

The results of this study show that the hotels have higher liquidity and activity ratios compared to the restaurants. Furthermore, the restaurants have higher profitability and solvency ratios, which means they are more capable to satisfy their long-term debts. It can be concluded that restaurants can have equal or even better performance when compared with their profit-oriented counterparts.

This study detects likely future studies by underlining the performance analysis on restaurants and hotels. There is a lack of studies enabling generalization of the results of one economy to another. Therefore, taking inputs from this research along with other research works done relevant to the emerging economies, the researchers can try to establish a trend between these economies concerning the performance analysis on Restaurant and Hotel industry. Such a trend can also be determined for the advanced economies which will allow generalization of results to all other economies that lack study within this research area. Therefore, researchers can use this research gap to further develop studies that test the same variables in other countries based on categorical classification of the economies. 


\section{REFERENCES}

Abdul Aziz, A. \& Rahman, A. (2017). The Relationship between Solvency Ratios and Profitability Ratios: Analytical Study in Food Industrial Companies listed in Amman Bursa. International Journal of Economics and Financial Issues, 7(2), 86-93.

Arif, T. M. H., Noor-E-Jannat, K., \& Anwar, S. R. (2016). Financial Statement and Competitiveness Analysis: A Study on Tourism \& Hospitality Industry in Bangladesh. International Journal of Financial Research, 7(4), 180-189.

Aslan, T., \& Yılmaz, E. (2018). Oran Analizi Yöntemi İle Konaklama Ve Yiyecek Hizmetleri Alt Sınıfındaki Küçük, Orta Ve Büyük Ölçekli İşletmelerin Finansal Performanslarının Karşılaştırmalı Analizi. Ida Academia Muhasebe ve Maliye Dergisi, 1(2), 36-52.

Bala, H., Garba, J., \& Ibrahim, I. (2016). Corporate liquidity and profitability of listed food and beverages firms in Nigeria. Net Journal of Social Sciences, 4(1), 10-22.

Bilici, N. S., \& Aydın, N. (2018). Konaklama İşletmelerinde Finansal Analizlere İlişkin Bir Örnek Olay İncelemesi. Atatürk Üniversitesi Sosyal Bilimler Enstitüsü Dergisi, 22(4), 2333-2355.

Böcskei, E. (2014). Profitability and Efficiency - An analysis of the Financial Impact of the Szechenyi Plan In The Hungarian Hospitality Industry. Applied Studies in Agribusiness and Commerce, 8(4), 51-56.

Chen, M. H. (2010). The economy, tourism growth and corporate performance in the Taiwanese hotel industry. Tourism Management, 31(5), 665-675.

Damitio, J., Schmidgall, R. S., \& Dennington, L. J. (1995). Financial statement analysis. Bottomline, 10(6), 10-23.

De, A., Bandyopadhyay, G., \& Chakraborty, B. N. (2011). Application of the Factor Analysis on the Financial Ratios and Validation of the Results by the Cluster Analysis: An Empirical Study on the Indian Cement Industry. Journal of Business Studies Quarterly, 2(3), 13-31.

Delen, D., Kuzey, C., \& Uyar, A. (2013). Measuring Firm Performance Using Financial Ratios: A Decision Tree Approach. Expert Systems with Applications, 40(10), 3970-3983.

Ecer, F., \& Günay, F. (2014). Borsa İstanbul'da işlem gören turizm şirketlerinin finansal performanslarının gri ilişkisel analiz yöntemiyle ölçülmesi. Anatolia: Turizm Araştırmaları Dergisi, 25(1), 35-48.

Erdogan, A. (2014). Applying Factor Analysis on the Financial Ratios of Turkey's Top 500 Industrial Enterprises. International Journal of Business and Management, 8(9), 134-139. doi: 10.5539/ijbm.v8n9p134

Feng, C. M., \& Wang, R. T. (2000). Performance evaluation for airlines including the consideration of financial ratios . Journal of Air Transport Management, 6(3), 133-142.

Karadeniz, E., İskenderoğlu, Ö., Kahiloğulları, S., \& Zencir, B. (2014). Türkiye Cumhuriyet Merkez Bankası Sektör Bilançoları Yardımıyla Konaklama Ve Yiyecek Hizmeti Faaliyetleri Alt Sektörünün Likidite Durumunun Analizi. 15. Ulusal Turizm Konresi, $701-710$.

Karadeniz, E., \& Kahiloğulları, S. (2014). Akdeniz Bölgesi’nde Faaliyet Gösteren Beş Yıldızlı Otel İşletmelerinde Finansal Analiz Tekniklerinin Kullanımı. Eskişehir Osmangazi Üniversitesi İktisadi ve Idari Bilimler Dergisi, 9(1), 73-90.

Karataş, A. (2002). Performance of Direct Foreign Investments in Turkey. Unpublished Doctoral Thesis, Institute of Social Sciences, Bogazici University, Istanbul.

Kim, W. G., \& Ayoun, B. (2005), "Ratio Analysis for the Hospitality Industry: A Cross Sector Comparison of Financial Trends in the Lodging, Restaurant, Airline, and Amusement Sectors", The Journal of Hospitality Financial Management, 13(1), 59-78. doi: 10.1080/10913211.2005.10653800

Kim, H. B., \& Kim, W. G. (2005). The Relationship Between Brand Equity and Firms' Performance in Luxury Hotels a nd Chain Restaurants. Tourism Management, 26(4), 549-560.

Lai, J. H. (2018). Performance and Risk: Hotel Company in France-Pierre \& Vacances. https://dx.doi.org/10.2139/ssrn.3182160

Mardahleni, M. (2018). Profitability Ratio Analysis in Evaluating Financial Performance of Pt. Hanjaya Mandala Sampoerna, TBK. e-Jurnal Apresiasi Ekonomi, 6(3), 269-275.

MEGEP (2011). Konaklama ve Seyahat Hizmetleri. MEB Yayınları, Ankara.

Naumik-Gladkaya, E. G., \& Devon, V. V. (2018). World Luxury Hotels and Key Financial Ratıos/Prıces/Trends Analyze. Комунальне господарство міст, 143, 2-8.

Ocal, M. E., Oral, E. L., Erdis, E., \& Vural, G. (2007). Industry Financial Ratios - Application of Factor Analysis in Turkish Construction Industry. Building and Environment, 42(1), 385-392. doi: 10.1016/j.buildenv.2005.07.023

Özçelik, H., \& Kandemir, B. (2015). BIST'de İşlem Gören Turizm İşletmelerinin Topsıs Yöntemi Ille Finansal Performanslarının Değerlendirilmesi. Balikesir University Journal of Social Sciences Institute, 18(33), 97-114.

Pudjisuryadi, P., Lumantarna, B., Setiawan, R., \& Handoko, C. (2018). Performance of an Existing Reinforced Concrete Building Designed in Accordance to Older Indonesian Seismic Code: A Case Study for a Hotel in Kupang Indonesia. Civil Engineering Dimension, 20(1), 35-40. 
Singh, A. J., \& Schmidgall, R. S. (2001). Use of ratios by financial executives in the US lodging industry. The Journal of Hospitality Financial Management, 9(1), 27-44.

Singh, A. J., \& Schmidgall, R. S. (2002). Analysis of financial ratios commonly used by US lodging financial executives. Journal of Retail \& Leisure Property, 2(3), 201-213.

Şen, L., Zengin, B., \& Yusubov, F. (2015). Otel İşletmelerinde Finansal Analizlere İlişkin Bir Örnek Olay İncelemesi. İ̧̧letme Bilimi Dergisi, 3(1), 64-85.

Tan, L. Y. (2018). Analysis Relationship between Financial Variables and Market Risk in Accorhotels. https://dx.doi.org/10.2139/ssrn.3181642 Tamallo, E. (2018). Analisis Kinerja Keuangan Pada Hotel Grand Asia Di Makassar. AKMEN Jurnal Ilmiah. 15(1), 40-54.

Turizmin (2011). Turizmin Tarihsel Gelişimi. Available at: http://www.goktepe.net/turizmin-tarihsel-gelisimi-2.html (accessed 18 March 2018).

Uğurlu, M., \& Aksoy, H. (2006). Prediction of corporate financial distress in an emerging market: the case of Turkey. Cross Cultural Management: An International Journal, 13(4), 277-295. doi: 10.1108/13527600610713396

Vaško, Ž., Ostojić, A., \& Drinić, L. (2018). Financial Performance Analysis of the Companies in the Agricultural Sector and Food Industry in the Republic of Srpska. АГРОЗНАњE, 19(2), 67-78.

Vatalis, A. (2018). Financial Analysis of the Biggest Hotel Companies. Unpublished Master's Thesis. International Hellenic University, Greece.

Ziskos, C. (2019). Financial Analysis for Public Greek Hospitality Sector Companies. Unpublished Master's Thesis. International Hellenic University, Greece. 